\title{
ESTUDO PRELIMINAR SÔBRE A LOCALIZAÇÃO RENAL DE COM- PLEXOS ANTÍGENO-ANTICORPO EM RATOS INFECTADOS COM PLASMODIUM BERGHEI *
}

\author{
Carlos Eduardo Tosta *:
}

São apresentados os resultados preliminares de um estudo evolutivo da localizaçấo renal de complexos antígeno-anticorpo solúveis em ratos infectados com P. berghei. Embora no $2 .^{\circ}$ dia o animal já apresentasse parasitos circulantes e no $60^{\circ}$ dia fôsse demonstrado anticorpos circulantes, sòmente no $12 .^{\circ}$ dia ficou caracterizada a presença simultânea de antígeno e anticorpo, por imunofluorescência, nos glomérulos e arteriolas renais, correspondendo a uma queaa do nivel sérico de complemento. No $160^{\circ}$ dia o depósito glomerular era minimo e o complemento retornou a niveis considerados normais.

Após um confronto com os dados obtidos em outros trabalhos o A. sugere Gue o P. berghei possa apresentar uma ação patogênica para o hospedeiro através da formação de complexos $A g-A c$ embora acentuando a necessidade de estudos adicionais.

\section{INTF઼ODUÇÃO}

A deposição de complexos antígenoanticorpo (Ag-Ac) em estruturas vasculares e sua posterior lesão constitui um mecanismo de hipersensibilidade comum a diversas condições clínicas como o lupus eritematoso disseminado, a glomerulonefrite e a dcença do sôro, entre outras. Por razōes hemodinâmicas próprias, e não por uma afinidade especial da membrana basal (1) o rim é o órgão que mais sofre a ação lesiva dêstes complexos.

Em doenças infecciosas, anàlogamente, um mesmo mecanismo poderia estar presente resultando đa reação de antígenos secretados pelos microrganismos ou liberados em decorrência de sua lise, com anticorpos específicos do hospedeiro.
A maior incidência de síndrome nefrótica em habitantes de áreas endêmicas de malária na África vem merecendo a atenção de diversos pesquisadores. A possibilidade de um mecanismo imunológico, sugerida pela demonstração de anticorpos maláricos na urina dêsses pacientes(5) e pela ausência de parasitos no local das lesões renais(4) foi reforçada pela demonstração de depósitos glomerulares de gamaglobulina e de complemento (C') (2) e pela presença de complexos Ag-Ac circulantes associada à alteração do nível sérico de complemento (8). Contudo, só recentemente, foi caracterizada a presença simultânea no glomérulo de antígeno plasmódico, gamaglobulina e complemento, sugerindo a ação patogênia do $P$. $m a-$ lariae atrávés da formação de complexos

* Trabalho da Clinica de Doenças Infectuosas e Parasitárias da F.M. da U.F.R.J. e do Instituto Brasileiro de Troplcologia Médica, Cx. Postal 1859, Rio de Janejro.

** Bolsista do Conselho Naclonal de Pesquisas. 
Ag-Ac(15). Também experimentalmente foram evidenciados, por imunofluorescência, os três componentes de complexos patcgênicos (Ag-Ac-C') no rim de Macaca mulatta durante a infecção por Plasmodium cynomolgi( 7 ).

Relatamos nesta nota os resultados preliminares de um estudo evolutivo da deposiçāo de complexos Ag-Ac em rins de ratos infectados com $P$. berghei.

\section{MATERIAL E MÉTODOS}

Foram inoculados sete ratos albinos, do sexo masculino, de 3 meses de idade, de linhagens consanguíneas e mantidos nas mesmas condiçōes ambientais $\mathrm{e}$ de alimentação. Utilizou-se uma cêpa de Plasmodium berghei proveniente da Divisāo de Zoologia do Instituto Oswaldo Cruz (Rio de Janeiro) e mantida em nosso laboratório por repiques semanais em camundongos Swiss-55. As inoculações foram feitas por via intraperitoneal com $0,25 \mathrm{ml}$ de sangue diluído em salina (1:4) contendo um mínimo de $40 \%$ de hemácias parasitadas. Três animais morreram na fase aguda da doença. Os demais foram sacrificados no $2 .^{\circ}, 6 .^{\circ}, 12 .^{\circ}$ e $16^{\circ}$ dia de infecção, após contrôle de parasitemia. Os órgãos foram divididos sendo uma parte fixada em formol para estudo histológico e a outra congelada em mistura de gêlo-sêco + acetona e cortada em criostato (sessões de $4 \mu$ de espessura).

Utilizou-se para a dosagem do complemento hemolítico no sôro um micrométodo adaptado da técnica de Kwapinski (in Kwapinski \& Snyder (6), e para a avaliação do título de anticorpos circulantes empregou-se o método de imunofluorescência, indireto, preconizado por Voller(12). Os anticorpos depositados nos tecidos foram demonstrados por tratamento com gamablobulina fluorescente anti-rato e os antígenos pelo método indireto de imunofluorescência.

\section{RESULTADOS}

Embora o número reduzido de animais analisados não permita uma avaliação cronológica precisa, os dados obtidos são sugestivos da ação de complexos Ag-Ac.
No $2 .^{\circ}$ dia de infecçāo, quando a parasitemia era mínima ( 380 parasitos $/ \mathrm{mm}^{3}$ ) e o nível de complemento sérico dentro dos limites normais $(96 \%)$, não foram demonstrados anticorpos circulantes nem qualquer alteração renal. No $6 .^{\circ}$ dia, correspondendo a uma elevação da parasitemia ocorreu intensa anticorpogênese esplênica demonstrada por imunofluorescência e os anticorpos circulantes alcançaram o título de 1:320. Nesta ocasião, demonstrou-se nos glomérulos um depósito mínimo de material fluorescente de provável origem plasmódica e o complemento sérico não apresentava alterações significativas (Fig. 1). Já no $12 .^{\circ}$ dia, relacionada a uma queda do nível sérico do complemento para $60 \%$ (segundo Tosta (9), os valôres normais para ratos jovens, hígidos estão compreendidos entre 80 e $96 \%$ ) (Fig. 2), evidenciou-se a presença simultânea de anticorpos (Fig. 3) e de antígeno plasmódico (Fig. 4) nos glomérulos e arteríolas renais (Fig. 5), quando o título de anticorpos circulantes era de 1:1280. No $16 .^{\circ}$ dia, os depósitos renais eram mínimos, o complemento se elevou para $80 \%$ embora o animal apresentasse plasmódios no sangue circulante e o título de anticorpos se mantivesse no nível anterior.

\section{DISCUSSÃO E CONCLUSÃO}

Como demonstraram Germuth \& McKinnon(3) os complexos Ag-Ac apresentam ação patogênica quando formados em ligeiro excesso de antigeno para que sejam suficientemente pequenos para serem solúveis e, portanto, circulantes mas também suficientemente grandes para serem capazes de reagir com o complemento que, através de uma ação quimiotáxica(14), levaria ao acúmulo de polimorfonucleares no local, com posterior lesão de estrutura. Tanto o excesso de anticorpos como de antígeno pode impedir o desenvolvimento da lesão(1), tendo mesmo Valdes \& cols. (10) comprovado a possibilidade de regressão das lesões renais por depósito de complexos solúveis através da administração de excesso de antígeno.

Êstes dados poderiam ser transpostos para o estudo da malária. O material antigênico capaz de formar complexos, secre- 


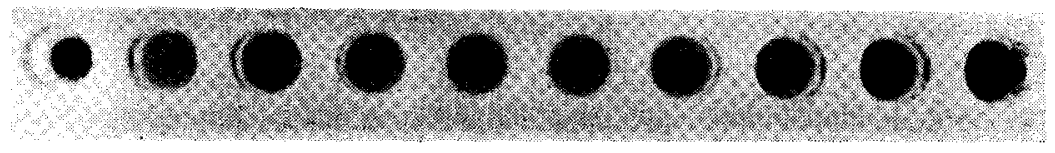

Fig. 1 --. Rato no $6^{\circ}$ dia de infecção. Complemento hemolítico apresentando niveis normais no sôro $(94 \%)$

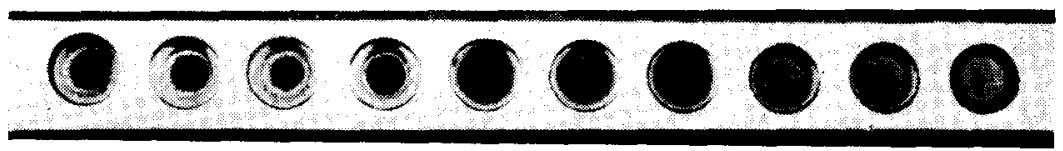

Fig. 2 - Rato no $12^{\circ}$ dia de infecção. Complemento hemolítico apresenta uma queda significativa $(60 \%)$.

tado pelo plasmódio ou decorrente de sua degradação, estaria em relação direta com o grau de parasitemia, podendo ser indicado por ela. Assim justifica-se a ausência de complexos patogênicos na fase inicial da infecção, quando há um grande predomínio de antígeno e o excesso de anticorpo, a partir do $12 .^{\circ}$ dia, alterando o equilíbrio anterior, poderia ser o responsável pela menor evidenciação de complexos no $16 .^{\circ}$ dia, idéia que é reforçada pela elevação do nível de complemento sérico.

A disposição difusa e o aspecto finamente granular do material fluorescente depositado no glomérulo (Fig. 3) possuem caracteríšticas comparáveis aos padrões obtidos por outros autores em casos de glomenulonefrite por depósito de complexos solúveis (10) e o achado de acentuada fluorescência na camada elástica interna de arteriolas renais é explicado pelo depósito "in loco" de complexos Ag-Ac já que esta estrutura age, como acontece com a membrana basal dos glomérulos, como sụerfífície :iltrante(1).

Poderíamos concluir que os dados apresentados são favoráveis à hipótese de que o $P$. berghei pode exercer uma ação patogênica através da formação de complexos Ag-Ac solúveis necessitando-se, porém, estudos adicionais.

\section{AGRADECIMENTOS}

Agradecemos aos Professôres J. Rodrigues Coura, Paulo F. A. Lopes e Car-

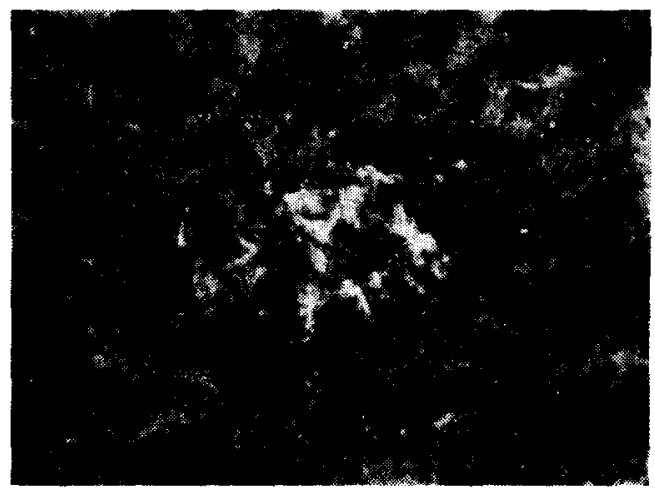

4Fig. 3 Glomérulo de animal sacrificado no 12 - dia de infecção apresentando depósitos de anticorpos $\therefore$ fluorescentes de distribuição difusa aspecto $\therefore$ finamente granular.

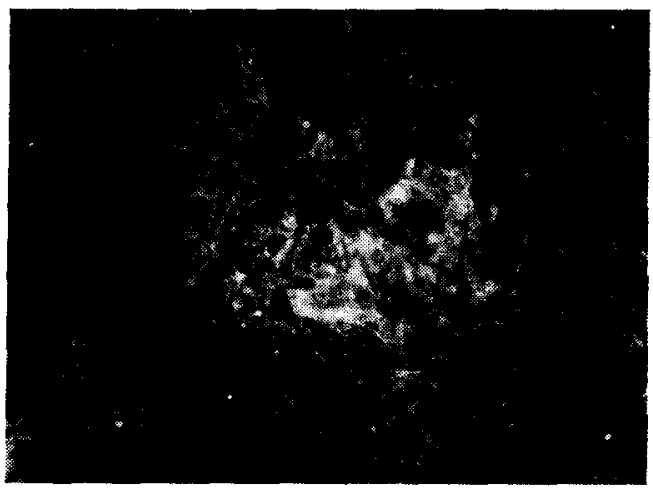

Fig. 4 - Mesmo animal apresentando material antigênico demonstrado pela técnica de imunofluorescencia indireta. 


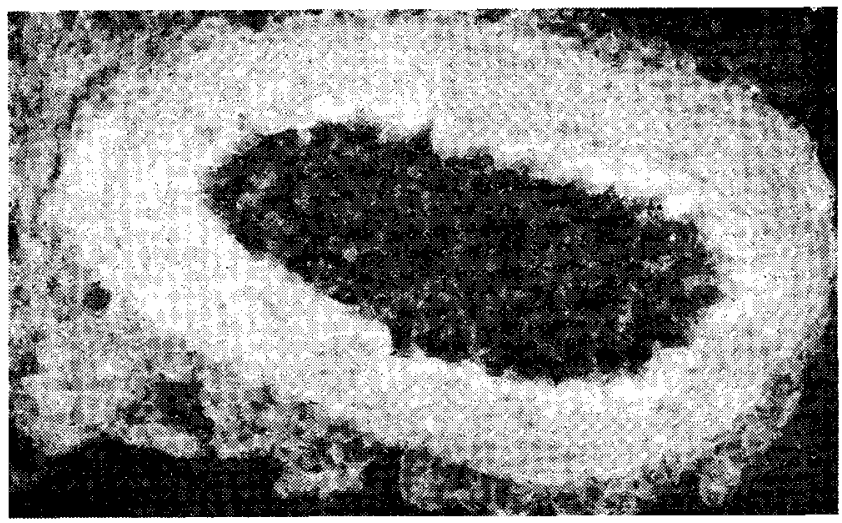

Fig. 5 - Arferiola renal apresentando material antigênico (IF indireta) en sua parede o mais acentuadamente na linifante plástica interna. Com a técnica empregada para demonstraçäo de anticorpos obteve-se o mesmo padrão de fluorescência.

los E. Serpa a orientação e o apoio, ao Dr. Jorge E. Atkins da O.P.A.S. o auxílio na obtenção de material bibliográfico, ao Dr. Nelson Coelho Pereira a ajuda cons- tante na ex€cução do trabaho e ao Sr. Jorge dos Remédios pelo material fotográfico.

\section{SUMMARY}

This report is the result of a preiminary study of the demonstration of entigen-antibody complexes in the kidney of albino rats infected with Plasmodium berghei. Although the presence of parasites in the peripheral blood was demonstrated on the 2nd day of infection and the circulating antibodies on the 6th day by the fluorescent antibody technique, it was only on the 12th day that there were found deposits of antigen and antibody in the glomeruli and on the internal elastic lamina associated with a decrease of the level of the hemolytic complement in the serum. On the 16th day the glomeruli presented a minimum deposit and the complement reached normal levels.

The author suggests that $\mathrm{P}$. berghei can act as a pathogen to the host by means of formation of soluble antigen-antibody complexes. However, this subject needs additional study.

\section{BIBLIOGRAFIA}

1. COCHRANE, C. G. \& DIXON, F. J. Cell and tissue damage through antigen-antibody complexes in Textbook of Immunopathology (edited by P. A. Miescher and H. J. Müller-Eberhard) pp. 94-110, 1968. Grune \& Stratton, New York and London.

2. DIXON, F. J. - Mil. Med. 131:1233, Citado por Ward \& Kibukamusoke 1969.

3. GERMUTH, F. G. \& MCKINNON, G. E. - Studies on the biological properties of antigen-antibody comple- xes. I. Anaphylactic shock induced by soluble antigen-antibody complexes in unsensitized normal guinea pigs. Bull. Hopkins Hosp. 101: 13, 1957.

4. KIBUKAMUSOKE, J. W. \& HUTT, M. S. R. - Histological features of the nephrotic syndrome associated with quartan malaria. J. Clin. Path. 20: 117, 1967.

5. KIBUKAMUSOKE, J. W. \& WILKS, N. E. - The appearance of malaria antibodies in the nephrotic urines. East African Med. J. 42: 203, 1965 . 
6. KWAPINSKI, J. B. \& SNYDER, M. L. - The Immunology of Rheumatism. Appleton - Century, Crofts. New York, 1962.

7. O. M. S. -. Immunología del Paludismo. Informe de un Grupo Científico de la Organización Mundial de la Salud n. ${ }^{\circ} 396,1968$.

8. SOOTHILL, J. F. \& HENDRICKSE $R$. G. - Some immunological studies of the nephrotic syndrome of Nigerian children. Lancet Sept. 23-629, 1967.

9. TOSTA, C. E. - Dados a serem publicados.

10. VALDES, A. J., SENTERFIT, L. B., POLLACK, A. D. \& GERMUTH, F. G. JR. .- The effect of antigen excess on chronic immune complex glomerulonephritis. Johns Hopkins Med. J. 124: 9, 1969.

11. VERNIER. R. L. - Glomerulonephritis in Textbook of Immunopathology (edited by P. A. Miescher and H. J. Müller - Eberhard) pp. 365 - 389, 1968. Grune \& Stratton, New York and London.

12. VOILER, A. - Fluorescent antibody methods and their lise in malaria research. Bull. World Health Org. 30: $343,1964$.

13. VOLLER, A. ... Immonofluorescence and humoral immunity to Plasmodium berghei. Ann. Soc. Belge Med. Trop. 45: 385, 1965.

14. WARD, P. A., COCHRANE, C. G. \& MÜLLER-EBERHARD, H. J. - The role of serum complement in chemotaxis of leukocytes in vitro. J. Exp. Med. 122: 327, 1965.

15. WARD, P. A. \& KIBUKAMUSOKE, J. W. - Evidence for soluble immune complexes in the pathogenesis of the glomerulonephritis of quartan malaria. Lancet, Feb. 8-283, 1969. 